\title{
Allelopathic Mechanisms in Fire-Prone Ecosystems
}

\begin{tabular}{|c|c|}
\hline \multicolumn{2}{|c|}{$\begin{array}{l}{ }^{1} \text { Department of Biology, Kastamonu University, } 37150 \text { Kastamonu, Turkey } \\
{ }^{2} \text { Department of Forest Engineering, Kastamonu University, } 37150 \text { Kastamonu, Turkey } \\
{ }^{*} \text { Corresponding author }\end{array}$} \\
\hline ART ICLE INFO & A B S T R A C T \\
\hline $\begin{array}{l}\text { Keywords: } \\
\text { Allelopathy } \\
\text { Fire Prone Ecosystems } \\
\text { Succession } \\
\text { Fire Ecology } \\
\text { Allelochemicals }\end{array}$ & $\begin{array}{l}\text { Understanding the fire-prone arid-zone pine species and maquis vegetation's response to fire is very } \\
\text { important to reveal the ecology and evolution of these species. During the succession of vegetation, } \\
\text { there are complex relationships between allelopathic metabolites and fires. Many plant communities } \\
\text { such as pines, maquis, savannas and woodlands are known to play a critical role in the development } \\
\text { of succession. However, studies revealing the relationship between succession processes and } \\
\text { allelopathic mechanisms in fire-prone ecosystems are quite limited. Most evergreen maquis } \\
\text { vegetations are one of the most studied fire ecosystems. In maquis vegetation, fire causes the } \\
\text { formation of plant communities that continue with allelochemicals produced by plants, as well as } \\
\text { shaping the climate of the region. The event of a living species inhibiting another species by secreting } \\
\text { toxic compounds is expressed as allelopathy. These toxic compounds are generally referred to as } \\
\text { allelochemicals. Many maquis species that grow in fire-prone ecosystems excrete their } \\
\text { allelochemicals, preventing the development of herbaceous species around them and invade their } \\
\text { habitats. These chemicals, which accumulate in the soil during the dry season, affect the succession } \\
\text { processes in vegetation in the event of a fire and determine which species will follow each other. } \\
\text { Considering these relationships, it can be said that allelopathic plants have the potential to change } \\
\text { plant diversity in vegetation by changing their functional plant characteristics. The purpose of this } \\
\text { review is to determine the relationship between allelochemicals and fire of plant species in fire-prone } \\
\text { ecosystems, and to reveal how this affects the succession processes. }\end{array}$ \\
\hline
\end{tabular}

Türk Tarım - Gıda Bilim ve Teknoloji Dergisi, 9(6): 1100-1105, 2021

\section{Yangına Eğilimli Ekosistemlerde Allelopatik Mekanizmalar}

\begin{tabular}{|c|c|}
\hline M A K A L E B İ L G İ S İ & Ö Z \\
\hline $\begin{array}{l}\text { Anahtar Kelimeler: } \\
\text { Allelopat } \\
\text { Yangına Eğilimli Ekosistemler } \\
\text { Süksesyon } \\
\text { Yangın Ekolojisi } \\
\text { Allelokimyasallar }\end{array}$ & $\begin{array}{l}\text { Yangına eğilimli kurak bölge çam türleri ve maki vejetasyonlarını oluşturan bitkilerin yangına karşı } \\
\text { geliştirdikleri tepkileri anlamak, bu türlerin ekolojisini ve evrimini ortaya çıkarmak adına oldukça } \\
\text { önemlidir. Vejetasyonun süksesyon sürecinde, allelopatik metabolitler ile yanginlar arasında } \\
\text { karmaşık ilişkiler bulunduğu ve yangının; maki, savanalar ve ormanlık alanlar gibi birçok bitki } \\
\text { topluluğunun süksesyon gelişiminde kritik bir rol oynadığı bilinmektedir. Ancak yangına eğilimli } \\
\text { ekosistemlerdeki süksesyon süreçleri ve allelopatik mekanizmalar arasındaki ilişkiyi ortaya koyan } \\
\text { çalışmalar oldukça sınırlıdır. Geneli herdem yeşil maki vejetasyonları en çok çalış1lan yangın } \\
\text { ekosistemlerinden birisidir. Maki vejetasyonlarında yangın; bitkiler tarafından üretilen } \\
\text { allelokimyasallarla birlikte en iyi şekilde yetişen ve devamlılık gösteren bitki topluluklarının } \\
\text { oluşmasına neden olarak o bölgenin klimaksının oluşmasını sağlar. Bir canlı türünün toksik bileşikler } \\
\text { salgılayarak, başka bir canlı türünü engellemesi olayı allelopati olarak ifade edilmektedir. Bu toksik } \\
\text { bileşikler genel olarak allelokimyasal olarak nitelendirilir. Yangına eğilimli ekosistemlerde yetişen } \\
\text { birçok maki türü sahip oldukları allelokimyasalları dışarı salgılayarak çevrelerinde bulunan otsu } \\
\text { türlerin gelişimini engellemekte ve habitatlarını işgal etmektedirler. Kurak mevsimde toprakta biriken } \\
\text { bu kimyasallar da herhangi bir yangın anında vejetasyondaki süksesyon süreçlerini etkileyerek, hangi } \\
\text { türlerin birbirini izleyeceği konusunda belirleyici olmaktadır. Bu ilişkiler göz önüne alındığında, } \\
\text { allelopatik bitkilerin, fonksiyonel bitki karakterlerini değiştirerek vejetasyondaki bitki çeşitliliğini } \\
\text { değiştirme potansiyeline sahip olduğu söylenebilir. Bu derlemenin amacı, yangına karşı eğilimli olan } \\
\text { ekosistemlerde bulunan bitki türlerinin sahip olduğu allelokimyasallar ve yangın arasındaki ilişkinin } \\
\text { belirlenmesi ve bu durumun süksesyon süreçlerine nasıl bir etkisi olduğunun ortaya çıkarılmasıdır. }\end{array}$ \\
\hline
\end{tabular}




\section{Introduction}

Fire has an important role in structuring ecological systems and plant communities from savannas to meadows, boreal forests to shrubs and forest areas (Tyler, 1995; Küçük ve Bilgili, 2006; Aktepe, 2021). The common phenomenon for many of these fire-prone plant communities is the realization of plant germination by performing different adaptations in order to survive after the fire and renew itself (Tyler, 1995; Keeley et al.2011; Pausas, 2015). In his work, Axelrod (1958) suggested that fire has been an effective force in the progress of chaparral/maquis communities for at least the last two million years. In addition to being the most important cause of secondary succession in these communities (Hanes, 1977), fire is also responsible for the continuity of chaparral communities (Keeley and Keeley 1988). Mature chaparral/maquis communities, defined as large bushes, consist of species that can survive for many years and show little regeneration in the lower vegetation. While significant seed progress is observed in the first year after fire, decades must pass before new species emerge (Tyler, 1995). Although there have been many studies on the succession processes in the chaparral/maquis communities, there is little empirical research on the relative importance of the factors affecting these processes (Tyler, 1995). Fire is one of the important factors that affect these processes. Fire causes rapid progress in chaparral/maquis communities directly and indirectly after combustion. This development can take place in two ways. First, the soil and the seed bank are heated directly, seed germination takes place, allelochemicals are blown away by changing soil structure and nutrient levels. Second, by eliminating the above-ground vegetation, it reduces the allelochemical effects and temporarily drop off competition. In areas where small mammals usually feed on shrubs, it temporarily reduces the activity of herbivores.

The direct burning of fire and its indirect effects (competition and decrease in herbivores) caused an increase in seedling production in chaparral/maquis communities (Tyler 1995). Studies on allelopathy have increased rapidly since 1970 and have become an interesting subject in many research areas. Allelopathic interaction is one of the important factors contributing to species distribution and abundance in plant communities (Cheng \& Cheng, 2015; Abou El-Enin \& Abdel-Ghffa 2017). Allelopathy is the phenomenon where a living species secretes toxic compounds and prevents the development of another species. These toxic compounds are generally referred to as allelochemistry. For example, algae secrete substances that have important effects on the structure and functions of aquatic communities. Likewise, some substances secreted by the leaves and roots of advanced plants may have detrimental and harmful effects on other living things. Blacknut trees (Juglans nigra) secrete an allelochemical substance, juglone, in order to prevent the development and germination of the plant species around (Willis, 1985). These allelopathic metabolites are washed away from the rash in the rainy environment. In arid climates, on the other hand, its effects are more common as it tends to accumulate.

Recent studies have revealed that there are complex relationships between allelopathic metabolites and fires in the process of sequential change (succession) in plant communities in arid regions (such as desert and maquis vegetation). These allelopathic metabolites are washed away from the rash in the rainy environment. In arid climates, on the other hand, its effects are more common as it tends to accumulate. Whittaker and Feeny (1971), Rice (1974), Harborne (1982), Gopal and Goel (1993), and Seigler (1996) discussed in detail the role of biochemical secretions in the development and structuring of communities (Odum and Barrett 2005).

However, there is no comprehensive study concerning the relationship between allelopathy and fire. In literature on allelopathy generally deals with the effects of allelopathy on germination and seedling (Aguilar-Franco et al., 2019), plant performance (Zhang et al., 2021) and invasive plant species (Uddin and Robinson, 2017). Although there are not also many studies in the Turkish literature on allelopathy, it mainly deals with the effects of allelopathy on plant production (Yarnia et al., 2011; Gürsoy et al., 2013) invasive plant species (Arıkan and Elibüyük, 2015; Kitiş et al., 2016; Özen et al., 2017; Karakuş et al., 2019), seed germination and seedling development (Gülsoy et al., 2008; Akın et al., 2017; Bingöl and Battal, 2017; Özbay, 2018; Yorulmaz and Yergin, 2020). However, studies on allelopathy require the examination of the interaction between the associated plant species and fire, as this ecological phenomenon is caused by the effect of allelochemicals. In this context, the contribution of the study to the existing fire ecology and botanical sciences is to find out the effects of allelopathy on succession processes and fire plant species.

The purpose of this review is to determine the relationship between allelochemicals and fire of plant species in ecosystems that are prone to fire, and to reveal how this affects the succession processes. For this purpose, the study focuses on the relationship between fire, succession and allelopathy. The study reveals how allelopathic effects play a role in the change of system dynamics, especially in fire-prone ecosystems. In this context, the study presents a different perspective to fire ecology in the field of environmental studies by evaluating the chemical properties of plants.

\section{Allelopathy}

Allelopathy can be defined as the effect of one species on another species by releasing allelochemicals in the plant's body to the environment (Rice, 1974). It has been determined that allelochemicals obtained by extracting plant leaves and roots are effective on many of the physiological mechanisms of other plants (Rice, 1974; Putman and Tang, 1986). When these effects are taken into consideration, it is seen those plants with allelochemicals have the potential to change the number of species and individuals in that community by affecting the functional plant characteristics of the plants that show the distribution in their vegetation (Hunter and Menges 2002). Interaction between plants typically refers to either competition for resources (e.g., food, light, water) or chemically regulated (e.g., allelopathy) interaction (Fernandez et al., 2016). Overall, resource competition is an important driver for the diversity and 
dynamics of the plant community (Tilman, 1982; Schluter, 2000). However, recent studies show that allelopathy has a significant role in the formation of plant communities that include different vegetations (Fernandez et al., 2016). When describing allelopathy in Mollish (1937), it was used to denote all effects caused by biochemical compounds that are directly or indirectly transferred from one plant to another. In the studies conducted so far, the effect of allelochemicals on plants as well as on algae, fungi and various microorganisms have been studied. The current definition of allelopathy was extended to the literature by the International Allelopathy Society in 1996 to address processes involving secondary substances produced by fungi, microorganisms, plants and viruses that affect agricultural and biological processes (Cheng and Cheng 2015).

\section{Allelopathic Metabolites}

Allelopathy is a biological event in which a living thing releases compounds that prevent another creature from reproducing, developing and surviving. These secreted compounds are known as allelochemicals and they can have a positive or negative effect on the living things (Cheng and Cheng 2015). Substances that do not have nutritional properties and are secreted as plant secondary metabolites are called allelochemicals. Allelochemicals belong to different chemical families and are examined in 14 categories according to their chemical similarity (Rice, 1974) (Table1).

Especially compounds such as salicylic acid, gibberellic acid and ethylene, that act as regulators in plant growth, are described as allelochemicals. Recent studies have made it possible to insulate and describe very small proportions of allelochemicals and reveal the structural analysis of these molecules (Cheng and Cheng 2015). The fact that most of the allelochemicals also cause insect resistance is a proof that many plants perform plant defense by using allelochemicals. It is demonstrated that allelopathic effects directly affect metabolic processes, resulting in secondary expressions (Einhellig, 1995a; Einhellig, 1995b). While evaluating the effects of plants with high allelopathic properties, the effects of allelochemicals responsible for allelopathy should also be revealed.

Studies have allowed the classification of different allelopathic compounds (Gallet and Pellissier, 1997; Wink et al., 1998; Inderjit and Keating, 1999b). Cell division, membrane permeability, germination, plant conduction tissues, mineral uptake, movement of stomata, respiration, amino acid synthesis, photosynthesis and nitrogen fixation are among the best examples that can be given to the areas affected by allelochemicals (Wink et al., 1998, Kruse et al., 2000). It has a wide spectrum of activity of many alelochemicals. Phenolic compounds such as alkaloids, lignin and terpenes are among the most important allelochemicals. Many of the alkaloids have been found to be toxic to plants, microorganisms, mammals and many insect species (Wink et al., 1998). In addition, they are known as multi-functional defense agents due to their wide range of actions. This situation reveals that determining how the allelochemical substances secreted by the plant affect the diversity of other plant species requires an ecosystem approach (Gallet and Pellisier, 1997). Terpenoids and alkaloids together with phenolic compounds form plant secondary metabolites. The most important phenolic compounds are known as flavonoid, lignin, terpene and tannin. Recent studies have revealed that among these compounds, terpenes, in particular, are effective in the formation of fire and plant flammability (Kruse et al., 2000; Pausas et al., 2016; Küçük and Aktepe 2017). Terpenes are synthesized by plants with more than 15,000 known varieties (Langenheim, 1994). It is known that many plant species found in fire-prone vegetations produce and secrete high amounts of volatile terpenes. In addition, terpenes have an important role in the survival and participation of plants in defense mechanisms against pathogens, herbivores and environmental factors (Gouinguene \& Turlings, 2002; Peñaflor and Bento, 2013). In addition, they regulate the competition between rival plants (Gniazdowska and Bogatek, 2005). However, very few studies have shown that the secondary metabolites with carbon structure and the competition of plants with each other are dependent on environmental factors. In Mediterranean type ecosystems where fire occurs frequently, competition among plants is the most important environmental factor (Sardans et al., 2004; Küçük et al., 2005; Sağlam et al., 2008). As the plant begins to compete for soil, nutrients and other resources necessary for its growth, the rate of photosynthesis, its development, and the amount of nitrogen are reduced (Wang et al., 2005). Fluctuations in these factors change the amount of terpenes secreted by the plant (Staudt et al., 1993). Terpenes are moderately abundant in many plants (Banthorpe et al., 1972), but in high-rise plant species they are stored in special structures in only 50 families (Gildemeister and Hoffmann, 1955-1960). Although terpenes are thought to have a very large range of action, they can be quite specific in dosage in different plant communities and organisms (Kruse et al., 2000).

Table 1. Allelochemicals belong to different chemical families

\begin{tabular}{|c|c|c|c|}
\hline \multicolumn{4}{|c|}{ Allelochemicals } \\
\hline 1 & purines and nucleosides & 8 & simple unsaturated lactones; \\
\hline 2 & flavonoids; & 9 & tannins; \\
\hline 3 & long chain fatty acids and polyacetylenes; & 10 & terpenoids and steroids; \\
\hline 4 & benzoquinone, anthraquinone and complex quinones; & 11 & amino acids and peptides; \\
\hline 5 & alkaloids and cyanohydrins; & 12 & simple phenols, benzoic acid and derivatives; \\
\hline 6 & cinnamic acid and derivatives; & 13 & sulfur and glucosinolates; \\
\hline 7 & coumarin; & 14 & $\begin{array}{c}\text { aliphatic aldehydes and ketones; } \\
\text { water soluble organic acids, } \\
\text { straight chain alcohols, }\end{array}$ \\
\hline
\end{tabular}




\section{Exploring the Relationship Between Fire and} Succession

Fires are quite common in chaparral/scrub vegetation. The plant species found in these vegetations have developed different adaptations that allow them to regenerate and survive after a fire (Keeley et al., 2011; Pausas, 2015). These adaptations developed by plants against fire appeared in the form of (1) fire dependency or (2) fire tolerance. The species that are dependent on fire are those that can sprout again after a fire. These species consume very little energy for the above-ground reproductive organs and use their energy to develop the subsurface storage organs. Thus, when the above-ground organs die after the fire, new shoots and new individuals emerge from the underground organs rapidly. Fire-tolerant species are those that die when they reach mature age. Unlike the fire-dependent species, these species produce abundant and resistant seeds. These seeds, which do not burn easily during fire, have the ability to germinate immediately after the fire (Keeley et al., 2011). The most studied fire ecosystems are chaparral/maquis vegetation, most of which consist of maquis that can remain green in all seasons. In these ecosystems, the fire interacts with allelochemicals generated by plants, creating a site-specific climax cycle. Periodically occurring and external disruptive factors such as fire, especially in temperate ecosystems, significantly affect the recession process (Hanes, 1977).

In regions with Mediterranean climates, where spring and winter are generally rainy and summers are dry and long, fires occur most frequently in the dry season and little or no plant development occurs before the next rainy season begins (McPherson and Muller, 1969; Küçük ve Sağlam, 2004). In this case, new growth begins from the underground parts of some maquis and the seeds of many maquis' species germinate rapidly and in large quantities. Herbaceous plant species germinate in large numbers following the onset of the rainy season after fire (Horton and Kraebel, 1955; McPherson and Muller, 1969). The interesting thing about this is those mature chaparrals usually have few or no herbaceous species. After a fire, herbaceous plant species are most prominent in the first growing season. These species consist of annual grasses, biennials, tuber-forming perennials, and short-lived semis. In the second growing season after the fire occurs, weeds and herbaceous species appear. After the second growing season, a rapid decrease begins in the number and vitality of herbaceous plant species (McPherson and Muller, 1969). More than 200 herbaceous species have been reported in fire-stricken areas, the majority of which are annuals. Some of these herbaceous species disappear after the first year and are called "pyrophyte endemic" (Hanes 1977; Keeley et al., 1985). Based on the study by Sampson (1944), McPherson and Muller found that the weed population decreased by about $25 \%$ in the fifth growing season compared to the first year. Few herbaceous plant species have been observed to germinate seeds seven to nine years after the fire. On the other hand, the halfdwellers reach their maximum numbers in the third and fourth seasons after the fire and then gradually their numbers begin to decrease. Finally, about 12 years after the fire, very few herbaceous plant species or semi-shrubs remained (Rice and Kozlowski 1974).

\section{Understanding the Allelopathic Effect in the Ecosystem: Interactions between Fire and Allelopathy}

Woody plants in fire-prone vegetations have evolved different adaptations for survival and reproduction in response to sudden but acute forest fires. Adult plant species develop different mechanisms to escape genetic death (death without reproduction). Woody species often survive surface fires if they have thick, insulating bark and are tall enough to prevent scorching damage to twigs and buds. If the seeds of the plant fruit exposed to the crown fire are released in the form of a serotiny shell and seed bank, they will colonize again in the soil formed after the fire. These strategies demonstrated by the plant are the fire adaptations that the individual performs in order to regenerate and survive. These adaptations shown by plants are directly related to variables such as fire frequency, fire intensity and fire period. These variables are dependent on some environmental factors such as precipitation, temperature and, lightning strike and biotic factors such as the plant itself (Mutch, 1970; Platt et al., 1988; Rebertus et al., 1989). In other words, the responses of plants and the way they create debris are highly effective in regulating fire variables in a society. For instance, the fall of leaves and dead branches causes frequent but less severe fires, while the retention of dead branches and leaves in the plant causes less frequent but more intense crown fires. Likewise, a dense bush layer increases crown fires, while dense debris cover increases surface fires (Williamson et al., 1992). The studies of C. H. Muller on chemical inhibitors produced by shrub species growing in chaparral vegetation in California can be given as classic examples of allelopathy. In these studies, both chemical properties and physiological effects of these inhibitors on other species were revealed. Furthermore, these inhibitors have been found to significantly control the species composition and dynamics of the chaparral/scrub community (Muller et al., 1964; Muller, 1966; Muller et al., 1968, Muller, 1969).

Some aromatic scented shrub species avoid the improvement of herbaceous plant species in their immediate surroundings with the volatile terpenes they release. Salvia leucophylla and Artemisia californica, which are among the aromatic species, thrive in an area covered with herbaceous annual plants, prevent the improvement of these annual plants and occupy their habitats with the biochemical inhibitors they secrete. Volatile toxins (especially cineole and camphor) are generated in the leaves of these shrubs and accumulate in the soil during the arid season. The seeds of other plant species that have come to a few meters wide margin around the bush after it has rained cannot germinate or are prevented from growing. Some other types of shrubs produce other types of water-soluble antibiotics (eg phenols and alkaloids). These antibiotics also prevent the growth of other plant species in the immediate vicinity of the bush. Thus, the resources in the environment such as water, nutrients and light can only be used by the bush type itself (Odum and Barrett 2005). However, fires are a natural part of chaparral/scrub ecosystems. These fires, which occur periodically, on the one hand remove the 
shrub species that are the source of toxins from the area, on the other hand, they degrade and decompose the toxins accumulated in the soil.

Different herbaceous plant species with colorful flowers germinate and develop in the first rainy season following the fire, when the aromatic shrubs and toxins are eliminated. However, these herbaceous plants can only sustain their existence in this way for a few years. Because in the years following the fire, the seeds of the aromatic bushes germinate and develop again in the same area and start to emit toxins again. For this reason, herbaceous plants cannot grow in this area until another fire occurs. These interactions between fires and antibiotics continue with repetitive cyclical changes in the chaparral/scrub composition adapted to these factors. Allelopathic effects determine which species will follow each other during the succession process in a plant community. In addition, the allelopathic effect also affects the species composition in stable plant communities. Chemical interaction between species can both decrease and increase species diversity. The extracted chemicals cause a decrease in species diversity with their inhibitory (allelopathic) effects in some communities, while in some communities they increase species diversity by acting as a chemical supporter (especially in the creation of some new ecological niches) (Odum and Barrett 2005).

\section{Conclusion and Discussion}

Evidence from C. H. Muller and colleagues revealed that the allelopathic effects of many shrubs found in California chaparral communities are mainly responsible for the fire cycle. The chemical inhibition exerted by mature shrubs has been found to be sufficient to prevent the seeds of most plants from germinating. The evidence clearly shows that fires release the allelopathic effects of shrubs by clearing out sources of toxins, removing some of the toxins found in soil and debris. Thus, the regeneration of a new plant arises from seeds that have been dormant in the soil since the previous fire and are no longer blocked by toxins. As the bushes stand out again after the fire, so does the competitive intervention that emphasizes the increased addition of toxins and any inhibition caused by the toxins.

\section{References}

Abou El-Enin MM, Abdel-Ghffa MAF. 2017. Allelopathic effect of peanut, sunflower and corn crops on germination and growth of some winter weeds. Archives of Agriculture and Environmental Science, 2(4): 257-263.

Aguilar-Franco Zoila, Alejandro Flores-Palacios, FloresMorales, Alejandro, Perea-arango I, Arellano Jesus, Valencia Díaz Susana. 2019. Density-dependent effect of allelopathy on germination and seedling emergence in two Ipomoea species. Revista Chilena de Historia Natural 92: 7.

Akın B, Akanıl Bingöl N, Leblebici S. 2017. Lythrum salicaria L. Ekstraktlarının Marul Tohumlarının Çimlenmesi ve Fide Gelişimi Üzerine Allelopatik Etkisi. Akademia Disiplinlerarası Bilimsel Araștırmalar Dergisi, 3(1): 23-30.

Aktepe N. 2021. Kızılçam (Pinus brutia Ten.) ormanlarında bitkilerin yanabilirliğinin popülasyon, tür ve komünite düzeyindeki değişkenliği ve bu değişkenliğin yangın rejimi ile ilişkisi. Doktora Tezi, Hacettepe Üniversitesi Fen Bilimleri Enstitüsü, Ankara.
Arıkan N, Elibüyük İ. 2015. Yabancı Otlarla Mücadelede Allelopatinin Kullanımı. Türk Bilimsel Derlemeler Dergisi, (1): 46-50

Axelrod DI. 1958. Evolution of the Madro-Tertiary geo flora. The Botanical Review, 24: 433-509.

Banthorpe DV, Charlwood BV, Francis MJO. 1972. The biosynthesis of monoterpenes, Chemical Reviews 72: 115155.

Bingöl Ö, Battal P. 2017. Verbascum cheiranthifolium Boiss. var. asperulum (Boiss.) Murb. ve Salvia limbata C. A. Mey. Ekstraktlarının Zea mays L. ve Portulaca oleraceae L. Tohumlarının Çimlenmesi Üzerine Allelopatik Etkisinin Araştırılması. Türkiye Tarımsal Araştırmalar Dergisi, 4(2): 176-185.

Cheng F, Cheng Z. 2015. Research Progress on the use of Plant Allelopathy in Agriculture and the Physiological and Ecological Mechanisms of Allelopathy. Frontiers in Plant Science, 6:1020.

Einhellig FA. 1995a. Allelopathy - Current Status and Future Goals. In Allelopathy: Organisms, Processes and Applications. (ed. Inderjit, KMM Dakshini and FA Einhellig). American Chemical Society, 1-24

Einhellig FA. 1995b. Mechanisms of action of allelochemicals in allelopathy. In Allelopathy. Organisms, processes, and applications. ACS Symposium Series 582 (ed. Inderjit, KMM Dakshini and FA Einhellig). American Chemical Society, Washington, DC.,96-116.

Fernandez C, Monnier Y, Santonja M, Gallet C, Weston LA, Prévosto B, Bousquet-Mélou A. 2016. The impact of competition and allelopathy on the trade-off between plant defense and growth in two contrasting tree species. Frontiers in Plant Science, 7: 594.

Gallet C, Pellissier F. 1997. Phenolic compounds in natural solutions of a coniferous forest. Journal of Chemical Ecology, 23: 2401-2412.

Gildemeister E, Hoffman F. 1955-1960. Die atherischen Ole. Akademie Verlag, Berlin, 8 vol.

Gniazdowska A, Bogatek R. 2005. Allelopathic interactions between plants. Multisite action of allelochemicals, Acta Physiologiae Plantarum, 27: 395-407.

Gopal B, Goel U. 1993. Competition and allelopathy in aquatic plant communities. Botanical Review, 59: 155-210.

Gouinguene SP, Turlings TCJ. 2002.The effects of abiotic factors on induced volatile emissions in corn plants, Plant Physiology, 129:1296- 1307.

Gülsoy S, Özkan K, Mert A, Eser Y. 2008. Ardıç Juniperus excelsa meyvesinden ve Yayla Kekiği Origanum minutiflorum yapraklarından elde edilen uçucu yağların kimyasal bileşimleri ve Karaçam Pinus nigra subsp. pallasiana tohumunun çimlenmesi üzerine allelopatik etkileri. Biyolojik Çeşitlilik ve Koruma, 1(2): 105-114.

Gürsoy M, Balkan A, Ulukan H. 2013. Bitkisel Üretimde Allelopati. Uludağ Üniversitesi Ziraat Fakültesi Dergisi, 27(2): 115-122.

Hanes TL. 1977. California chaparral. Terrestrial Vegetation of California (Ed. by M. G. Barbour \& J. Major), Wiley, New York, 414-470.

Harborne JB. 1988. Introduction to Ecological Biochemistry (Academic, London), pp. 302-337.

Horton JS, Kraebel CJ. 1955. Development of veg etation after fire in the chamise chaparral of southern California. Ecology, 36: $244-262$.

Hunter ME, Menges ES. 2002. Allelopathic Effects and Root Distribution of Ceratiola ericoides (Empetraceae) On Seven Rosemary Scrub Species. American Journal of Botany, 89(7): 1113-1118.

Inderjit, Keating KI. 1999b. Allelopathy: Principles, Procedures, Procecesses, and Promises for Biological Control. In: Advances in Agronomy. (Eds.) Sparks D.L. Academic Press, 67: 141-231. 
Karakuş S, Tiryaki D, Aydın İ, Atıcı Ö. 2019. Nepeta transcaucasica Grossh. Esansiyel Yağının Bazı Kültür Bitkileri ve Zararlı Otlar Üzerinde Herbisidal Etkisinin İncelenmesi. Doğu Fen Bilimleri Dergisi, 2(2): 69-79.

Keeley JE, Keeley SC. 1988. Chaparral. North American Terrestrial Vegetation (eds MG Barbour and WD Billings), Cambridge University Press, Cambridge.pp. 165-207.

Keeley JE, Morton BA, Pedrosa A, Trotter P. 1985. Role of allelopathy, heat, and charred wood in the ger mination of chaparral herbs and suffrutescents. Journal of Ecology, 73: 445-458.

Keeley JE, Pausas JG, Rundel PW, Bond WJ, Bradstock RA. 2011. Fire as an evolutionary pressure shaping plant traits, Trends in Plant Science, 16: 406-411,

Kitiş Y, Kolören O, Uygur F. 2016. Allelopathic Effects of Common Vetch (Vicia sativa L.) on Seed Germination and Development of Some Weed Species. Tarla Bitkileri Merkez Araştırma Enstitüsü Dergisi, 25(1): 100-106.

Kruse M, Strandberg M, Strandberg B. 2000. Ecological Effects of Allelopathic Plants- A Review. NERI Technical Report, No. 315, Ministry of Environment and Energy National Environmental Research Institute.

Küçük Ö, Sağlam B. 2004. Orman yangınları ve hava halleri. Kastamonu Üniversitesi Orman Fakültesi Dergisi, 4(2): 220231.

Küçük Ö, Bilgili E, Dinç Durmaz, B. 2005. Yangın potansiyelinin belirlenmesinde yanıcı madde haritalarının önemi. Türkiye Ormancılık Dergisi, 6(1): 104-116.

Küçük Ö, Bilgili E. 2006. The conveyance of fire behavior characteristics into practice by using Geographical Information Sysyems (GIS): A case study in Kastamonu. Kastamonu University, Journal of Forestry Faculty, 6(2): 262-273.

Küçük Ö, Aktepe N. 2017. Effect Of Phenolic Compounds on the Flammability in Forest Fires. International Journal of Engineering Sciences \& Research Technology, 6(4): 320327.

Langenheim JH. 1994. Higher plant terpenoids: a phytocentric overview of their ecological roles, Journal of Chemical Ecology, 20: 1223-1280.

Mcpherson JK, Muller CH. 1969. Allelopathic Effects of Adenostoma F Asciculatum ' "Chamise", In the California Chaparral. Ecological Monographs, 39: 177-198.

Molisch H. 1937. Der Einfluss Einer Pflanze Auf Die Andereallelopathie. Jena: Fischer.

Muller CH. 1969. Allelopathy as a factor in ecological process. Vegetatio 18: 348-357.

Muller CH, Hanawelt RB, McPherson JK. 1968. Allelopathic control of herb growth in the fire cycle of California chaparral. Bulletin of the Torrey Botanical Club 95: 225-231.

Muller CH, WH Muller, Haines BL. 1964. Volatile growth inhibitors produced by aromatic shrubs. Science 143:471473.

Muller CH. 1966. The role of chemical inhibition (allelopathy) in vegetational composition. Bulletin of the Torrey Botanical Club 93:332-351.

Mutch RW. 1970. Wildland fires and ecosystems- A hypothesis, Ecology 51.6: 1046-1051.

Odum EP, Barrett GW. 2005. Fundamentals of Ecology, 5th ed. Brooks / Cole, a Thomson Learning Company.

Özbay N. 2018. Bazı Tıbi Bitki ve Yabancı Ot Ekstraktlarının Biberin Çimlenme ve Fide Gelişimi Üzerine Etkisi. Türk Tarım ve Doğa Bilimleri Dergisi, 5(1): 81-85.

Özen F, Yaldız G, Çamlıca M. 2017. Yabancı Ot Mücadelesinde Bazı Aromatik Bitkilerinin Uçucu Yağlarının Allelopatik Etkisi. Uluslararası Tarım ve Yaban Hayatı Bilimleri Dergisi, 3(1): 40-48.

Pausas JG. 2015. Bark thickness and fire regime, Functional Ecology, 29: 315-327.
Pausas JG, Alessio GA, Moreira B, Segarra-Moragues JG. 2016. Secondary compounds enhance flammability in a Mediterranean plant, Oecologia, 180: 103-110.

Peñaflor MFGV, Bento JMS. 2013. Herbivore-Induced Plant Volatiles to Enhance Biological Control in Agriculture. Neotropical Entomology, 42: 331-343.

Platt WJ, Evans GW, Rathbun SJ. 1988. The population dynamics of a long-lived conifer (Pinus palustris). The American Naturalist, 131: 491-525.

Putman AR, Tang CS. 1986. The science of allelopathy. John Wiley and Sons, New York, New York, USA.

Rebertus AJ, Williamson GB, Moser EB. 1989. Longleaf pine and turkey oak mortality in Florida xeric sandhills. Ecology, 70: 60-70.

Rice EL. 1974. Allelopathy. New York: Academic Press.

Rice EL, Kozlowsk TT. 1974. Allelopathy. New York: Academic Press. 104-125.

Sağlam B, Küçük Ö, Bilgili E, Dinç Durmaz B, Baysal İ. 2008. Estimating fuel biomass of some shrub species (Maquis) in Turkey. Turkish Journal of Agriculture and Forestry, 32(4): 349-356.

Sampson AW. 1944. Plant succession and burned chaparral lands in northern California. Agricultural Experiment Station, University of California, Berkeley, Bulletin 685.

Sardans J, Roda F, Penuelas J. 2004. Phosphorus limitation and competitive capacities of Pinus halepensis and Quercus ilex subsp rotundifolia on different soils, Plant Ecology, 174: 305-317.

Schluter D. 2000. Ecological character displacement in adaptive radiation. The American Naturalist, 156: 4-16.

Seigler DS. 1996. Chemistry and mechanisms of allelopathic interactions. Agronomy Journal, 88: 876-885.

Staudt M, Kotzias D, Sparta C, Ciccioli P. 1993. Holm oak (Quercus ilex), a strong emitter of monoterpenes, In 'Proceedings of the First Italian Symposium on the Strategies and Techniques for the Monitoring of the Atmosphere', Rome, Italy. (Ed. P Ciccioli) 579-586.

Tilman D. 1982. Resource Competition and Community Structure. Princeton, NJ: Princeton University Press.

Tyler C. 1995. Factors Contributing to Postfire Seedling Establishment in Chaparral: Direct and Indirect Effects of Fire. Journal of Ecology, 83(6): 1009-1020.

Uddin Nazim, Robinson Randall. 2017. Allelopathy and resource competition: the effects of Phragmites australis invasion in plant communities. Botanical Sciences.

Wang LW, Showalter AM, Ungar IA. 2005. Effects of intraspecific competition on growth and photosynthesis of Atriplex prostrata, Aquatic Botany, 83: 187-192.

Whittaker RH, Feeny PP. 1971. Allelechemics: Chemical interaction between species. Science, 171: 757-770.

Williamson GB, Richardson DR, Fischer H. 1992. Allelopathic mechanism in fire-prone communities. In Allelopathy. Basic and applied aspects (ed. SJH. Rizvi and V. Rizvi), Chapman and Hall, London, 59-73.

Willis RJ. 1985. The historical bases of the concept of allelopathy. Journal of the Historty of Biology, 18: 71-102.

Wink M, Schmeller T, Latz-Bruning B. 1998. Modes of action of allelochemical alkaloids: Interaction with neuroreceptors, DNA, and other molecular targets. Journal of Chemical Ecology, 24: 1881-1937.

Yarnıa M, İkincikarakaya S, Rezaei F, Khawar K. 2011. Çavdar Kalıntılarının, Horoz İbiğinin (Amaranthus retroflexus L.) Toprakta Bulunan Tohum Miktarı ve Bitki Gelişimi Üzerine Etkisi. Journal of the Institute of Science and Technology, 1(2): 91-96.

Yorulmaz M, Yergin Özkan R. 2020. Allelopathic Effect of Jimson Weed (Datura stramonium L.) on Seed Germination. Türk Tarım ve Doğa Bilimleri Dergisi, 7(3): 793-797.

Zhang Z, Liu Y, Yuan L, Weber E, Van Kleunen M. 2021. Effect of allelopathy on plant performance. 